\title{
Effect of Cement Pollution on some Biochemical Parameters in the Blood Serum of Hamam AL-Alil Cement Factory Workers
}

\author{
Haitham L. Al-Hayali \\ Department of Biology \\ College of Science \\ Mosul University
}

(Received 28 /12/2008; Accepted 26/1/2009)

\begin{abstract}
Long time exposure to cement industry pollution leads to several health problems. This study was designed to investigate the effects on 55 workers which were divided into groups according to the departments of Hamam AL-Alil Cement Factory-Iraq. The biochemical parameters included in the study are: calcium, zinc, lactate dehydrogenase, alkaline phosphatase, acid phosphatase, glutathione and malonaldehyde.

The results showed that there was a significant increase in calcium, lactate dehydrogenase, alkaline phosphatase, acid phosphatase and malonaldehyde in workers serum which increased with increasing exposure time. The results also showed a significant decrease in glutathione and zinc in workers serum which increased with increasing exposure time in all factory department.
\end{abstract}

Key word: Cement Pollution, Ions, Enzymes, Glutathione, Malonaldehyde, Serum.

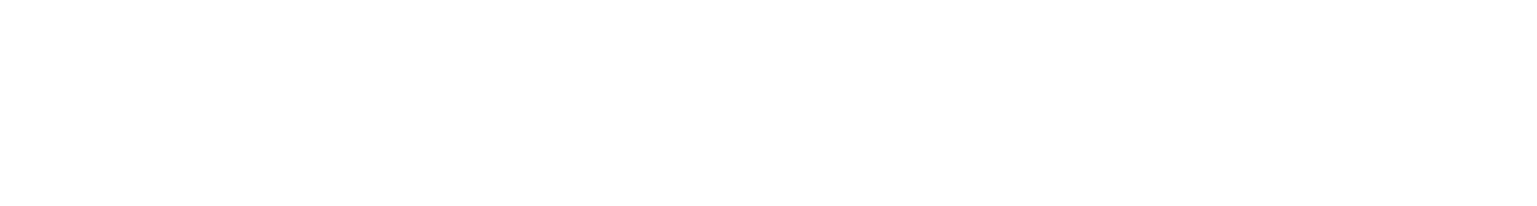

\section{المالغص}

إن التعرض المستمر لملوثلت صناعة الإمنت يؤدي إلى العديد من المشلكل الصحية. لذلك صممت الدرلسة للبحث في تأثير هذه الملوثلت على 55 علمل والذين م توزيعهم إلى مجلمبع مسب مواقع عمله م

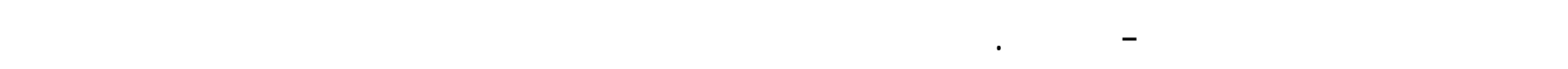
الكللسيو، الزك، اللهتيت ديهايدروجينيز الفوس فاتيز القاء دي، الفوس فاتيز الحلم ضضي، الكلوت اثيون والمالونالديهايد. لظٔلهرت النتائج بأن هناك زيادة معنوية في كل من مستوى اليونت الكللسيوم وأذزيم ـات اللكتي ـت ديهايدروجينيز والفوسفاتيز القاعدي والفوسفاتيز الحلمضي والمالونالديهايد مع انغفاض معنوي في م ستوى الكلوتاثيون وايونلت الزكك في مصل دم العلملين مع ازيياد فترة التعرض. 


\section{INTRODUCTION}

The major pollution problem in Portland cement factories is cement dust emission into the environment from various points of the production process such as Crusher, Kiln, Mills, Storage soils and Packing section (ILO, 1999). This resulted in the exposure of factory workers to cement dust leading to the impairment of respiratory function and a prevalence of respiratory diseases symptoms among workers (Mwaiselage et al., 2006).

Portland cement is composed of four major component: $\mathrm{CaO}, \mathrm{SiO}_{2}, \mathrm{Al}_{2} \mathrm{O}_{3}$ and $\mathrm{Fe}_{2} \mathrm{O}_{3}$ also trace elements: Cr, Zn, F, Mn, P, Sr, Na, Ti, K, Mg, and S. (Keith-Kirby and Kanare, 1988). Therefore, many of these elements are spread into the environment through air and affect human subsequently. The effect depends on time of exposure, type of work, location of work, residence and weather condition (AL-Omer, 2000).

Most of the trace elements are found in the human body in very minute quantities and any increase in some of them may have a toxic effect (AL-Sa'ady et al., 2000). These may be part of the chemical structure of the enzymatic systems or act as catalysts in the enzyme activity (AL-Omer, 2000).

Any variation in the enzyme activity is an indication of the effect of the pollution. Fewer studies have examined the effect on other systems. Therefore, the present study examined calcium and zinc levels, lactate dehydrogenase, alkaline phosphatase and acid phosphatase enzymes activity, also glutathione and malonaldehyde as a sample of non-enzymatic antioxidant and lipid peroxidation.

\section{Specimen Collection and Serum Preparation}

\section{MATERIALS AND METHODS}

The blood specimen collected from 55 workers of different departments of Hamam AL-Alil Cement Factory and from students and employees of Mosul University as the control group. $4-5 \mathrm{ml}$ of the drawn blood were put in plain tube, left to complete clot formation, the serum was then separated from the clotted blood by centrifugation at 3000 $\mathrm{rpm}$ for $15 \mathrm{~min}$., then decanted into clean and sterile plain tubes and stored at (-20) $\mathrm{C}^{\mathrm{o}}$.

\section{Estimation of Calcium and Zinc levels in Serum}

Atomic absorption spectroscopy (AAS) technique was used to determine $\mathrm{Ca}$ and $\mathrm{Zn}$ levels using the standard curve to convert the optical density into concentration (Zhang and Zhang, 2003).

\section{Estimation of Enzymes Activity in Serum}

Lactate dehydrogenase (LDH):

The LDH activity was determined using a BIOLABO-Reagent/France kit (Tietz, 1999).
Alkaline phosphatase (ALP):
The ALP activity was determined using a BIOMERIEUX Company/France kit (Kind and King, 1954). 
Acid phosphatase (ACP):

The ACP activity was determined using a BIOLABO-Reagent/France kit (Fishman and Lerner, 1953).

\section{Estimation of Glutathione and Malonaldehyde levels in Serum Glutathione (GSH):}

Glutathione level was determine by the modified Tietz (1999) method (AL-Zamely et al., 2001).

\section{Malonaldehyde (MDA):}

Malonaldehyde level was determine by the modified Gudie and Shah (1989) method Muslih et al., 2002).

\section{Statistical Analysis}

The statistical program (SPSS) was used to analyze the data (Indrayan and Sarkaddam, 2001).

\section{Ca and Zn levels:}

\section{RESULTES AND DISCUSSION}

The result showed that there was a significant increase in calcium ion level in the serum of cement workers especially at Mills and Kiln departments (Table 1). The result also indicated that there was a significant increase in calcium ion with increasing exposure time to cement pollution (Table 2).

The increase might be due to the fact that calcium compounds are the major components of Portland cement (Mwaiselage et al., 2005). Also heavy metals increase the acidity of the blood. The body draws calcium from the bones to help restore the proper blood $\mathrm{pH}$, further, toxic metals set up condition that lead to inflammation in arteries and tissues causing more calcium to be drawn to the area as a buffer (Pouls, 1999).

The calcium increase in the Kiln might be due to the large amount of fine materials produced during the Portland cement making process, these materials are carried out by the flow of hot gasses generated inside the kiln and not incorporated into the clinker (Maslehuddin et al., 2008).

These results agree with (Fatima et al., 1997) who found a significant increase in total protein and calcium level in the serum specimen of workers exposed to cement dust of Hyderabad Cement Factory-India. These parameters were increased with exposure time.

The results also showed a significant decrease in zinc ion level in workers serum of all departments of the factory especially in Cement Mill and Kiln departments (Table 1). A significant decrease with increasing exposure time was also observed (Table 2). The decrease could be caused by the dermatitis and eczema (Yanagisawa, 2004) which have resulted from dust exposure as $60 \%$ of the workers were found to suffer from dermatitis and eczema, or the zinc decreased with increasing calcium is observed by (Gill and Walton, 1979) who established that protein kinase activity is sensitive to inhibition by calcium ion which might be present in tissue extracts that causes many cell activities resulting in decreasing zinc level. 
Table 1: $\mathrm{Ca}$ and $\mathrm{Zn}$ levels in serum of cement workers depending on departments.

\begin{tabular}{|c|c|c|c|c|}
\hline \multirow{2}{*}{ Departments } & Ca (mg/100 ml) & \multirow{2}{*}{$\begin{array}{c}\% \\
\text { Increase }\end{array}$} & $\mathrm{Zn}(\mu \mathrm{g} / 100 \mathrm{ml})$ & \multirow{2}{*}{$\begin{array}{c}\% \\
\text { Decrease }\end{array}$} \\
\hline & Mean \pm SE & & Mean \pm SE & \\
\hline Control & $10.8 \pm 0.40^{\mathrm{a}}$ & - & $111.4 \pm 3.58^{b}$ & - \\
\hline Maintenance & $11.3 \pm 0.70^{\mathrm{a}}$ & 4.6 & $94.0 \pm 4.00^{\mathrm{a}}$ & 15.6 \\
\hline Crusher & $11.6 \pm 0.46^{\mathrm{a}}$ & 7.4 & $92.0 \pm 1.00^{\mathrm{a}}$ & 17.4 \\
\hline Raw mill & $12.2 \pm 0.50^{\mathrm{ab}}$ & 13.0 & $90.5 \pm 3.77^{\mathrm{a}}$ & 18.7 \\
\hline Cement mill & $12.4 \pm 0.47^{\mathrm{ab}}$ & 14.8 & $84.8 \pm 4.54^{\mathrm{a}}$ & 23.8 \\
\hline Kiln & $13.3 \pm 0.47^{b}$ & 23.1 & $80.2 \pm 6.19^{\mathrm{a}}$ & 28.0 \\
\hline Packing & $11.1 \pm 0.29^{\mathrm{a}}$ & 2.7 & $96.2 \pm 5.24^{\mathrm{ab}}$ & 13.6 \\
\hline
\end{tabular}

* Different letter vertically refers to presence of significant differences between treatment at $\mathrm{P} \leq 0.05$, according to Duncan - test.

Table 2: $\mathrm{Ca}$ and $\mathrm{Zn}$ levels in serum of cement workers depending on exposure time.

\begin{tabular}{|c|c|c|c|c|}
\hline \multirow{2}{*}{$\begin{array}{l}\text { Exposure } \\
\text { time }\end{array}$} & Ca (mg/100 ml) & \multirow{2}{*}{$\begin{array}{c}\% \\
\text { Increase }\end{array}$} & $\mathrm{Zn}(\mu \mathrm{g} / 100 \mathrm{ml})$ & \multirow{2}{*}{$\begin{array}{c}\% \\
\text { Decrease }\end{array}$} \\
\hline & Mean \pm SE & & Mean \pm SE & \\
\hline Control & $10.8 \pm 0.40^{\mathrm{a}}$ & - & $111.4 \pm 3.58^{b}$ & - \\
\hline $1-4$ & $11.6 \pm 0.73^{\mathrm{ab}}$ & 7.4 & $89.7 \pm 4.00^{\mathrm{a}}$ & 19.5 \\
\hline $5-8$ & $12.0 \pm 0.35^{\mathrm{ab}}$ & 11.1 & $88.9 \pm 0.00^{\mathrm{a}}$ & 20.1 \\
\hline $9-12$ & $12.6 \pm 0.88^{\mathrm{ab}}$ & 11.7 & $86.0 \pm 3.77^{\mathrm{a}}$ & 22.8 \\
\hline $13>$ & $13.2 \pm 0.46^{\mathrm{b}}$ & 22.2 & $84.0 \pm 4.54^{\mathrm{a}}$ & 24.6 \\
\hline
\end{tabular}

* Different letter vertically refers to presence of significant differences between treatment at $\mathrm{P} \leq 0.05$, according to Duncan - test.

\section{Enzymes Activity:}

\section{LDH}

The result indicated that there was a significant increase in the activity of LDH in the serum of cement factory workers, the highest activity was in the Cement mill, Maintenance and Packing departments (Table 3). The enzyme activity also increased with increasing exposure time (Table 4).

The increase might be due to the fact that LDH is especially concentrated in the heart, liver, red blood cells, kidney, muscles, brain and lungs, thus the damage of any of these organs could elevate LDH levels in serum. It was illustrated by (Drent et al., 1997) that lung-related disorders as a possible source of serum LDH abnormalities. Many researchers demonstrated that cement workers are susceptible to respiratory diseases (Noor et al., 2000 ; Laraqui et al., 2002 ; Fell et al., 2003).

The results agree with publication of (Cobben et al., 1997) who found that cell damage is increased in several pulmonary disorders and high level of LDH activity were found in rats exposed to silica, also (Gulumian et al., 2006) found that the increase in LDH activity and the membrane-bond enzyme ALP activity could be used as indicators of cell damage by crystalline silica. 
ALP

The result demonstrated that there was a significant increase in ALP activity in cement workers serum, the highest activity in the Mills and Packing departments (Table 3). Also the results showed that the enzyme activity increased in a proportional way with exposure time to cement pollution (Table 4). Increasing ALP activity might be due to exposure to heavy metals either by direct inhalation of suspended dust particles in air, dermal contact or indirect ingestion. Some of them are toxic and might interfere with enzymes system and metabolism of the body (Arogunjo, 2007).

The results are in agreement with (Mojiminiyi et al., 2007) who stated that the ALP activity increased proportionally with exposure time to cement dust in Sokoto Cement Factory-Nigeria and the highest activity was the Crusher, Cranes and Mills departments, also agree with other investigators (Struzak-Wysokinska et al., 1990) where the activity of ALP in workers exposed to cement dust was very high.

\section{ACP}

The result showed that there was a significant increase in ACP activity, maximum activity was at the Packing, Cement mill and Crusher departments (Table 3). Also the activity increased with increasing exposure time (Table 4). The increase might be due to that ACP is a hydrolytic lysosomal enzyme released during stress induced by tissue or cell damage (Jayakumar et al., 2008). Also the increasing in the activity of ACP in serum used as indicator of metal toxicity (Versteeg et al., 1988 ; Bull et al., 2002).

The results agree with the reported values of (Struzak-Wysokinska et al., 1990) where the activity of ACP increased with increasing intensity of pathological changes and increasing exposure to cement dust.

Table 3: Effect of cement pollution on LDH, ALP and ACP in serum of cement workers depending on departments.

\begin{tabular}{|c|c|c|c|c|c|c|}
\hline \multirow[b]{2}{*}{ Departments } & LDH ( IU/L) & \multirow{2}{*}{ o̊ } & ALP (U/L ) & \multirow{2}{*}{ ○ } & $\operatorname{ACP}(\mathrm{U} / \mathrm{L})$ & \multirow{2}{*}{ ○े } \\
\hline & Mean \pm SE & & Mean \pm SE & & Mean \pm SE & \\
\hline Control & $140.1 \pm 9.38^{\mathrm{a}}$ & - & $47.5 \pm 5.58^{\mathrm{a}}$ & - & $2.65 \pm 0.36^{\mathrm{a}}$ & - \\
\hline Maintenance & $259.0 \pm 37.5^{\mathrm{bc}}$ & 84.8 & $51.0 \pm 4.58^{\mathrm{a}}$ & 7.3 & $2.66 \pm 0.43^{\mathrm{a}}$ & - \\
\hline Crusher & $154.0 \pm 16.0^{\mathrm{ab}}$ & 10.0 & $52.0 \pm 5.57^{\mathrm{a}}$ & 9.4 & $6.10 \pm 1.23^{b}$ & 130.1 \\
\hline Raw mill & $179.6 \pm 36.6^{\mathrm{abc}}$ & 28.1 & $81.6 \pm 12.2^{a b}$ & 71.7 & $2.70 \pm 0.64^{\mathrm{a}}$ & 1.8 \\
\hline Cement mill & $251.0 \pm 28.1^{\mathrm{abc}}$ & 79.1 & $85.6 \pm 15.2^{a b}$ & 80.2 & $5.17 \pm 1.10^{a b}$ & 95.0 \\
\hline Kiln & $167.0 \pm 19.7^{\mathrm{ab}}$ & 19.2 & $58.6 \pm 8.33^{\mathrm{ab}}$ & 23.3 & $3.71 \pm 0.90^{\mathrm{ab}}$ & 40.0 \\
\hline Packing & $286.3 \pm 40.4^{\mathrm{c}}$ & 104 & $97.5 \pm 15.3^{b}$ & 105.2 & $3.80 \pm 0.52^{\mathrm{ab}}$ & 43.3 \\
\hline
\end{tabular}

- Different letter vertically refers to presence of significant differences between treatment at $\mathrm{P} \leq 0.05$, according to Duncan - test. 
Table 4: Effect of cement pollution on LDH, ALP and ACP in serum of cement workers depending on exposure time.

\begin{tabular}{|c|c|c|c|c|c|c|}
\hline \multirow{2}{*}{$\begin{array}{l}\text { Variables } \\
\text { Exposure } \\
\text { time }\end{array}$} & LDH ( IU/L) & ฆั & \multirow{2}{*}{\begin{tabular}{|l} 
ALP (U/L ) \\
Mean \pm SE
\end{tabular}} & \multirow{2}{*}{ 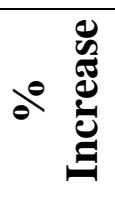 } & $\operatorname{ACP}(\mathrm{U} / \mathrm{L})$ & \multirow{2}{*}{ of } \\
\hline & Mean \pm SE & ه̊ & & & Mean $\pm \mathrm{SE}$ & \\
\hline Control & $140.1 \pm 9.38^{\mathrm{a}}$ & - & $47.5 \pm 5.58^{a}$ & - & $2.65 \pm 0.36^{\mathrm{a}}$ & - \\
\hline $1-4$ & $173.5 \pm 42.0^{\mathrm{ab}}$ & 23.8 & $60.5 \pm 7.17^{\mathrm{a}}$ & 27.3 & $3.04 \pm 0.48 \mathrm{ab}$ & 14.7 \\
\hline $5-8$ & $227.1 \pm 19.1^{\mathrm{ab}}$ & 62.0 & $67.8 \pm 7.72^{a}$ & 42.7 & $3.95 \pm 0.71^{\mathrm{ab}}$ & 49.0 \\
\hline $9-12$ & $189.5 \pm 3.50^{\mathrm{ab}}$ & 35.2 & $71.6 \pm 15.8^{a}$ & 50.7 & $4.15 \pm 1.15^{\mathrm{ab}}$ & 56.6 \\
\hline $13>$ & $272.0 \pm 41.3^{b}$ & 94.1 & $75.4 \pm 7.21^{\mathrm{a}}$ & 58.7 & $5.80 \pm 0.91^{b}$ & 118.8 \\
\hline
\end{tabular}

* Different letter vertically refers to presence of significant differences between treatment at $\mathrm{P} \leq 0.05$, according to Duncan - test.

\section{GSH and MDA levels:}

The result in (Table 5) showed that there was a significant decrease in GSH level in cement workers serum in some factory departments, the decrease was proportional to exposure time (Table 6). The decrease might be due to the leaching profile of cement-stabilized heavy metal ions, namely $\mathrm{Pb}, \mathrm{Cd}$, $\mathrm{As}$ and $\mathrm{Cr}$ besides the other pollutants (Halim et al., 2004). These compounds might enter in the bodies of cement workers through different ways and cause different internal effects (Aydin et al., 2004). Also the reduction in GSH level might be due to deficiency of the raw materials that are necessary to glutathione synthesis at oxidative stress like NADPH that resulting from pentoses pathway. This would stimulate glutathione reeducates enzyme to transform the active GSH from the inactive form-disulpher (Dickinson et al., 2003).

These results agree with others (Aydin et al., 2004 ; Orman et al., 2005 ; Al-Helaly, 2006 ; Ali, 2007) where they found that there was a significant decrease in antioxidant glutathione, superoxid dismutase, vitamin $\mathrm{C}$ and vitamin $\mathrm{E}$ in workers exposed to cement and silica pollution.

Results also showed that there were significant increase in lipid peroxidation MDA in workers serum of all cement factory departments (Table 5), the highest in Mills. Also the increase was proportional with exposure time (Table 6). The increase might be caused by the products resulting from lipid peroxidation. The most widely used index of peroxidation is MDA formation, it is also one of the principle products of the endoperoxidase (break down) in various disease (Dezewart et al., 1999; Valdimirov, 2004).

These results agree with others (Orman et al., 2005 ; Al-Helaly, 2006 ; Ali, 2007) where MDA level in workers exposed to silica and cement pollution were significantly higher and the direct measure of MDA and GSH could be accepted as an indicator of oxidative injury. Also the results agree with (Aydin et al., 2004) that some biochemical parameters were increased significantly like MDA level to $175 \%$, ALT $61 \%$ and AST 39\% in cement workers serum. 
Table 5: Effect of cement pollution on GSH and MDA levels ( $\mu$ mol/L) in serum of cement workers depending on departments.

\begin{tabular}{|l|c|c|c|c|}
\hline \multirow{2}{*}{ Departments } & GSH & \multirow{2}{*}{$\begin{array}{c}\text { MDA } \\
\end{array}$} & $\begin{array}{c}\text { Mean } \pm \text { SE } \\
\text { Decrease }\end{array}$ & $\begin{array}{c}\text { Mean } \pm \text { SE } \\
\text { Increase }\end{array}$ \\
\hline Control & $9.40 \pm 0.74^{\mathrm{b}}$ & - & $4.32 \pm 0.74^{\mathrm{a}}$ & - \\
\hline Maintenance & $5.55 \pm 1.21^{\mathrm{a}}$ & 41.0 & $11.37 \pm 2.76^{\mathrm{c}}$ & 163.1 \\
\hline Crusher & $6.30 \pm 1.45^{\mathrm{a}}$ & 33.0 & $6.87 \pm 0.31^{\mathrm{b}}$ & 59.00 \\
\hline Raw mill & $9.48 \pm 2.34^{\mathrm{b}}$ & - & $23.1 \pm 4.65^{\mathrm{e}}$ & 434.0 \\
\hline Cement mill & $6.33 \pm 1.39^{\mathrm{a}}$ & 32.6 & $15.2 \pm 3.99^{\mathrm{d}}$ & 251.0 \\
\hline Kiln & $9.30 \pm 0.91^{\mathrm{b}}$ & 1.00 & $5.40 \pm 0.85^{\mathrm{a}}$ & 25.00 \\
\hline Packing & $6.15 \pm 1.28^{\mathrm{a}}$ & 34.5 & $4.98 \pm 1.55^{\mathrm{a}}$ & 15.20 \\
\hline
\end{tabular}

* Different letter vertically refers to presence of significant differences between treatment at $\mathrm{P} \leq 0.05$, according to Duncan - test.

Table 6: Effect of cement pollution on GSH and MDA levels ( $\mu \mathrm{mol} / \mathrm{L})$ in serum of cement workers depending on exposure time.

\begin{tabular}{|l|c|c|c|c|}
\hline \multirow{2}{*}{$\begin{array}{l}\text { Vxposure } \\
\text { Variables }\end{array}$} & GSH & \% & MDA & \multirow{2}{*}{$\begin{array}{c}\text { \% } \\
\end{array}$} \\
& Mean \pm SE & Decrease & Mean \pm SE & Increase \\
\hline Control & $9.40 \pm 0.74^{\mathrm{b}}$ & - & $4.32 \pm 0.74^{\mathrm{a}}$ & - \\
\hline $\mathbf{1 - 4}$ & $8.34 \pm 1.63^{\mathrm{ab}}$ & 11.2 & $10.0 \pm 2.53^{\mathrm{b}}$ & 131.4 \\
\hline $\mathbf{5 - 8}$ & $8.31 \pm 0.92^{\mathrm{ab}}$ & 11.6 & $12.7 \pm 4.50^{\mathrm{bc}}$ & 194.0 \\
\hline $\mathbf{9 - 1 2}$ & $8.25 \pm 1.65^{\mathrm{ab}}$ & 12.2 & $20.2 \pm 3.99^{\mathrm{d}}$ & 367.0 \\
\hline $\mathbf{1 3}>$ & $7.41 \pm 2.69^{\mathrm{b}}$ & 21.1 & $15.1 \pm 2.95^{\mathrm{c}}$ & 249.0 \\
\hline
\end{tabular}

* Different letter vertically refers to presence of significant differences between treatment at $\mathrm{P} \leq 0.05$, according to Duncan - test.

\section{CONCLUSION}

Some biochemical analysis and antioxidant parameter seemed to be reliable and sensitive methods for detecting the damaged cells and fulfill the requirements of a biological marker of cement pollution exposure. Also these techniques might be considered as promising tools in biomonitoring studies on workers exposed to occupational hazards.

\section{ACKNOWLEDGMENT}

The researcher wishes to express his gratitude to the management and workers of Hamam AL-Alil Cement Factory for their valuable help in specimen collection especially, Mr. Saad Younis, also thanks are due to Mr. Yahya M. AL-Neaimy / College of Science for his valuable advice on the written work. 


\section{REFERENCES}

AL-Helaly, A.A., 2006. Antioxidant and some Biochemical Parameters in Workers Exposed to Pollutants in Mosul City. Ph. D. Thesis, College of Science, University of Mosul, Iraq.

Ali, M.A., 2007. Alternative of Some Biophysical Properties of Erythrocytes of Silicotic Patients. Romanian J. Biophys., 17(4): pp.225-236.

AL-Omer, M.A., 2000. Environmental Pollution. Dar AL-Awail for publishing. Oman. Jordan. (Arabic).

AL- Sa'ady, H.A.; Thaer, E.Q., and Mowafaq, H.M., 2000. The Toxic Effect of a Mixture of some Heavy Metals in Scenedesms quadricaudas. J. of Environ. Res. and Sustain. Develop., 3(2): pp.39-51. (Arabic).

AL-Zamely, O.M.; AL-Nimer, M.S., and Muslih, R.K., 2001. Detection the Level of Peroxynitrate and Related with Antioxidant Status in the Serum of Patients with Acute Myocardial Infection. Nat. J. Chem., 4: pp.625-637.

Arogunjo, A.M., 2007. Heavy Metal Composition of some Solid Minerals in Nigeria and Their Health Implications to the Environment. Pakistan J. of Biol. Sci. Monit., 10(24): pp.4438-4443.

Aydin, S.; Aral, I.; Kilic, N.; Bakan, I.; Aydin, S., and Erman, F., 2004. The Level of Antioxidant Enzymes, Plasma Vitamin C and E in Cement Plant Workers. Clin. Chim. Acta., 34(1-2): pp.193-198.

Bull, H.; Murray, P.G.; Thomas, D.; Fraser, A.M., and Nelson, P.N., 2002. Acid Phosphatases. J. Clin. Pathol., 55: pp.65-72.

Cobben, N.A.M.; Drent, M.; Schols, A.M.; Lamers, R.J.S.; Wouters, E.F.M., and Van Dieijen-Visser, M.P., 1997. Serum Lactate Dehydrogenase and its some Isoenzyme Partten in Ex-coalminers. Respir. Med., 91(10): pp.616-623.

Dezewart, L.L.; Neerman, J.H.N.; Commandeur, J.N.M., and Vermeuten, N.P.E., 1999. Biomarker of Free Radical Damage Applications in Experimental Animals and Humans. Free Radic. Biol. Med., 26: pp.202-226.

Dickinson, D.; Iles, K., and Forman, H., 2003. Signaling Pathways in Glutathione Biosynthesis. in: Proceedings of the 11th Biennial Meeting of the Society for Free Radical Research International, [Ed. C. Pasquier, and Bologna, Monduzzi]: pp.245-249.

Drent, M.; Cobben, N.A.M.; Henderson, R.F.; Wouters, E.F.M., and Van Dieijen-Visser, M.P., 1996. Usefulness of Lactate Dehydrogenase and its some Isoenzyme as Indicator of Lung Damage or Inflammation. Eur. Respir. J., 9: pp.1736-1742.

Fatima, S.K.; Ramana, D.Ch.V.; Aruna, P.P., and Reddy, P.P., 1997. Blood Serum Protein and Calcium Levels in Portland Cement Factory Workers. Indian J. Environ. Toxical., 7(2): pp.56-57.

Fell, A.K.; Thomassen, T.R.; kristensen, P.; Egeland. T., and Kongerud, J., 2003. Respiratory Symptoms and Ventilatory Function in Workers Exposed to Portland Cement Dust. J. Occup. Environ. Med., 45: pp.1008-1014.

Fishman, W.H., and lerner, F., 1953. A Method for Estimating Serum Acid Phosphatase of Prostatic Origin. J. Biol. Chem., 200: pp.89-97. 
Gill, G.N., and Walton, G.M., 1979. Assay of Cyclic Nucleotide-dependent Protein Kinases. In: Advances in Cyclic Nucleotide Research .press Book, Ltd, 114 Avenue of the Americas, New York. Vol., 10: pp.93-106.

Gulumian, M.; Borm, P.T.A.; Vallythan, V.; Castronova, V.; Donaldson, K.; Nelson, G., and Murrary, J., 2006. Mechanistically Identified Suitable Biomarkers of Exposure Effect and Susceptibility for Silicosis and Coal-worker's Pneumoconiosis: A comprehensive Review. J. of Toxicol. and Environ. health., 9 (B): pp.1-39.

Halim, C.E.; Scott, J.A.; Natawardaya, H.; Amal, R.; Beydoun, D., and low, G., 2004. Comparison Between Acetic Acid and Landfill Leachates for the Leaching of $\mathrm{Pb}$ (II), Cd (II), As (V), And Cr (VI) From Cementitious Wastes. Environ. Sci. Technol., 38(14): pp.3977-3983.

Indrayan, A., and Sarmukaddam, S.B., 2001. Medical Biostatics. Morcel Dekker, Inc, USA.: pp.299,303,405.

Jayakumar, P.; Jothivel, N., and Paul V.I., 2008. Heavy Metals Induced Alterations in the Acid Phosphatase Activity in the Edible Freshwater Mussel Lamellidens marginalis (Lamarck). Int. J. of Toxicol., 5(2) (http://www.ispub.com).

International Labour Organization, 1999. Encyclopedia of Occupational Health and Safety. 46 Geneva. Vol., 3(4): pp.44-93.

Keith-Kirby, R., and Kanare, M., 1988. Standard Reference Materials: Portland Cement Chemical Composition Standards (Blending, Packaging and Testing). National Bureau of Standards, Special Publication. Washington, D.C.: U.S. Government Printing Office: pp.103-110.

Kind, P.R.N., and King, E.G., 1954. Estimation of Plasma Phosphate by Determined of Hydrolyzed Phenol with Amino Antipyrine. J. Clin. Path., 7: pp.322-326.

Laraqui, H.Ch.; Laraqui, H.O.; Rahhali, A.E.; Tripodi, D.; Caubet, A.; Belamallem, I.; Verger, C.; Hakam, K., and Alaoui-Yazidi, A., 2002. Respiratory Symptoms and Ventilatory Disorders Among Group of Cement Workers in Morocco. Rev. Mal. Respir., 19(1-2): pp.183-189.

Maslehuddin, M.; AL-Moudi, O.S.B.; Shameem, M.; Rehman, M.K., and Ibrahim, M., 2008. Usage of Cement Kiln Dust in Cement Production. Research Review and Preliminary. Construction and building materials., 22 (12): pp.2369-2375.

Mojiminiyi, F.B.O.; Merenu, I.A.; Njoku, C.H., and Ibrahim, M.T.O., 2007. Regression Formulae for Predicting Hematologic and Liver Functions from Years of Exposure to Cement Dust in Cement Factory Workers in Sokoto, Nigeria. African J. of Biol. Med. Res., 10: pp.235-240.

Muslih, R.K.; AL-Nimer, M.S., and AL-Zamely, O.M., 2002. The Level of Malonaldehyde After Activation with $\left(\mathrm{H}_{2} \mathrm{O}_{2}\right.$ and $\left.\mathrm{CuSO}_{4}\right)$ and Inhibition of Desferoxamine and Molsidomine in the Serum of Patients with Acute Myocardial Infection. Nat. J. Chem., 5: pp.139-148.

Mwaiselage, J.; Bratveit, M.; Moen, B., and Yost, M., 2005. Variability in Dust Exposure in Cement Factory in Tanzania. Ann. Occup. Hyg., 49: pp.511-519.

Mwaiselage, J.; Moen, B., and Bratveit, M., 2006. Acute Respiratory Health Effects Among Cement Factory Workers in Tanzania: an Evaluation of a simple Health Surveillance Tool. Int. Arch. Occup. Environ. Health., 79(1): pp.49-56. 
Noor, H.; Yap, C.L.; Zolkepli, O., and Faridah, M., 2000. Effect of Exposure to Dust on Lung Function of Cement Factory Workers. Med. J. Malaysia., 55: pp.51-57.

Orman, A.; Kahraman, A.; Çakar, H.; Ellidokuz, H., and Serteser, M., 2005. Plasma Malondialdehyde and Erythrocyte Glutathione Levels in Workers with Cement Dust-exposure Silicosis. Toxicology, 207: pp.15-20.

Pouls, M., 1999. Oral Chelation and Nutritional Replacement Therapy for Chemical and Heavy Metal Toxicity and Cardiovascular Disease. In: Thousand Letters for Doctors and Patients Online Magazine.

Struzak-Wysokinska, M.; Bozyk, A., and Kaminska K., 1990. Enzymatic Tests for Alkaline and Acid Phosphatase in Gingival Tissues in Workers of the Chelm Cement Plant. Czas. Stomatol., 43: pp.654-660.

Tietz, N.W., 1999. Text Book of Clinical Chemistry. 3rd Edn. Philadelphia. W.B. Saunders Co.: pp.668-672.

Versteeg, D.J.; Graney, R.L., and Giesy, J.P., 1988. Field Utilization of Clinical Measures for the Assessment of Xenobiotic Stress in Aquatic Organisms. In Aquatic Toxicology and Hazard Assessment (Ed. William J.A. and Gary A.Ch.) ASTM Committee E-47 on Biological Effect and Environmental Fate. Vol., 10: pp.289306.

Valdimirov, Y.A., 2004. Reactive Oxygen and Nitrogen Species Diagnostic, Preventive And Theraps. Biochemistry, 69(1): 57p.

Yanagisawa, H., 2004. Zinc Deficiency and Clinical Practice. Japan Med. Assoc. J., 47(8): pp.359-364.

Zhang, X., and Zhang, C., 2003. Atomic Absorption and Atomic Emission Spectrophotometry. In : Handbook of Elemental Speciation. Techniques and methodology. (Ed. Comelis, R.; Grews, H.; Caruso, J. and Heumann, K.G.) Chichester John Wiley and Sons, pp.241-260. 